Susanne Steiner

\title{
Not just the what and how, but also the who: the impact of entrepreneurship educators
}

Book Part

This version is available https://doi.org/10.14279/depositonce-6677.

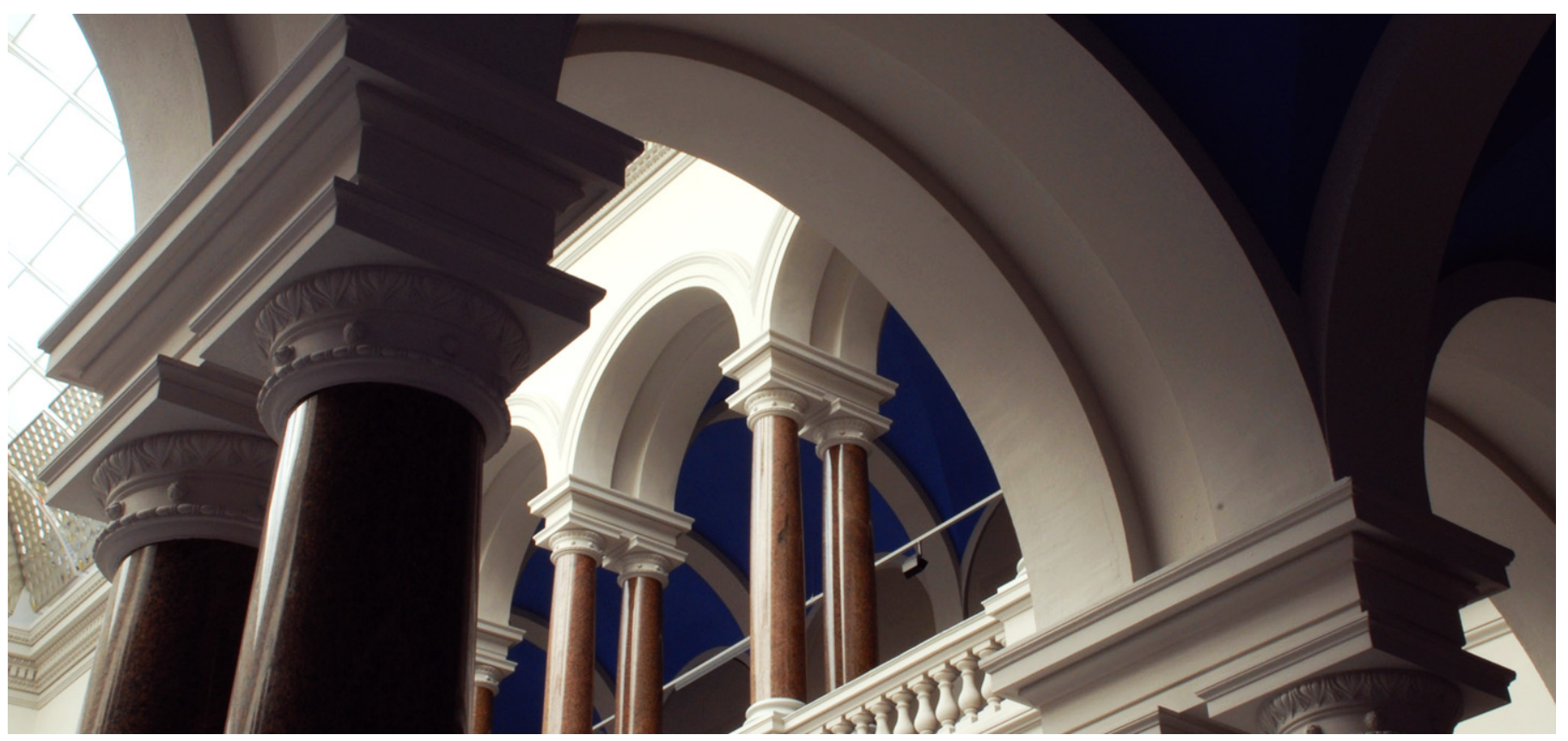

This is a draft chapter. The final version is available in Handbook on the entrepreneurial university edited by Alain Fayolle and Dana T. Redford, published in 2014, Edward Elgar Publishing Ltd http://dx.doi.org/10.4337/9781781007020. 


\section{Not just the What and How, but also the Who: the Impact of Entrepreneurship Educators}

"At an entrepreneurial university, teachers and instructors of entrepreneurship should be important intermediaries to raise awareness of entrepreneurship and to link academia to business in the long run." (Günther and Wagner, 2008, p. 403)

\section{Introduction}

The profile of entrepreneurship educators is as unexplored as it is diverse. While many studies in entrepreneurship education $(\mathrm{EE})$ look at students and their entrepreneurial learning process (e.g., Peterman and Kennedy, 2003; Fayolle et al., 2006; Pittaway and Cope, 2007; Müller, 2009), they have so far paid little attention to the profiles of educators.

Educators' profiles, however, might play a key role in the quality of delivery of EE. This study therefore aims at filling this research gap by analysing educator profiles and their potential impact. This interdependency has become all the more important in the course of striving towards the "entrepreneurial university" (Clark, 1998). National policymakers have increasingly set the target of developing entrepreneurial profiles for their higher education institutions (HEIs) (cf. Potter, 2008; Schleinkofer and Kulicke, 2009). But building and driving entrepreneurial universities will require faculties with suitable competencies, e.g. building networks between universities and external players.

Why look at e-educator profiles? What could be their impact on EE?

As the major carrier of these competencies, the entrepreneurship educator (e-educator) is not only one of the wide range of EE-stakeholders (cf. Matlay, 2010), but also plays the central role in meeting the requirements of an entrepreneurial university. "Academic autobiography" is known to influence teaching style (Fiet, 2001a, p. 4). Moreover, differences in EE-course design can result from an educator's "unwillingness or inability to view the world through other lenses" (Fiet, 2001a, ibid). A “competency trap" (Shepherd, 2004, p. 284) may result from 
this, andmay affect quality and effectiveness of entire EE-programmes. Therefore, this chapter analyses the profiles of e-educators and their impact on EE curricula and teaching methods as suggested by Shepherd (2004).

Existing academic publications on e-educators mostly deal with EE-programmes and methodologies, but not with educators. Little research has gone into "the systematic assessment" of e-educators, as Kabongo and McCaskey (2011, p. 28) have recently pointed out. Furthermore, the few publications on e-educators are based on case studies. The study by Hills (1988) is a prominent example of case study based research on EE-programmes: his survey of 15 leading e-educators in the USA evaluates the EE-programmes and their underlying objectives, but not the interviewed educators' profiles (cf. Henry et al., 2005a).

The few and heterogeneous references to educators themselves do not draw a coherent picture, reflecting the wide range of characteristics which e-educators currently show (Neck and Greene, 2011; Robbers, 2010). This apparent lack of consistency calls for the development of an occupational profile to "reduce arbitrariness" while preserving the "highly desirable and inevitable pluralism" among educator profiles (Robbers, 2010, p. 2). Meanwhile, the trend towards an increasingly wide range of EE-teaching and learning content both increases educator pluralism and reinforces the need for systematisation, e.g. an EE-typology (Haase and Lautenschläger, 2012).

Existing literature on e-educators reveals two further knowledge gaps. First, most published studies are US-focused (cf. Kabongo and McCaskey, 2011; Finkle, 2007; Finkle et al., 2007; Hills, 1988). However, US-based results might not be applicable to Europe, because EE might differ between the US and Europe. This would inevitably lead to geographical differences in educator profiles. Secondly, the few publications on European EE deal only marginally with the entrepreneurship educator (cf. Halbfas, 2006). Research on German-speaking countries 
only discusses EE-staff as a side aspect to the trend towards entrepreneurship chairs (Schleinkofer and Kulicke, 2009; Klandt, 2004). In sum, there is little information available on German educators other than full-time professors.

Our study fills some of the above mentioned gaps by analyzing the profiles of a sample of eeducators at German universities and their impact on EE-courses, exploring the following research questions and along the following structure:

1. What is already known about the profiles of current actors in EE?

2. How do e-educators at universities in Germany compare, and does a university's overall entrepreneurial performance have an impact on the profile of its e-educators?

3. Does an e-educator's profile have an influence on teaching contents of EE, and if so, how?

\section{In search of clarity: Who is the entrepreneurship educator?}

The earliest reference to the term "entrepreneurship educator" was made by Hills (1988, p. 112), followed by Katz and Green (1996, p. 371), and Fiet (2001b, p. 103). “Entrepreneurship scholar" was more often used (e.g., Fiet 2001a, p. 2), referring to both researchers and/ or instructors. A multitude of reference terms, as illustrated by the following table, reflects the diversity of individuals as well as the lack of a common occupational profile. 


\begin{tabular}{|c|c|c|c|c|c|}
\hline Authors (Journal) & Year & Term used & Focus on & Region & Methodology \\
\hline $\begin{array}{l}\text { Hills } \\
\text { (Journal of } \\
\text { Business } \\
\text { Venturing) }\end{array}$ & 1988 & $\begin{array}{l}\text { entrepreneurship } \\
\text { educator }\end{array}$ & EE-programmes & US & $\begin{array}{l}\text { Interviews with } \\
\text { leading scholars } \\
\text { / case studies of } \\
\text { EE-programmes }\end{array}$ \\
\hline $\begin{array}{l}\text { Katz and Green } \\
\text { (Simulation and } \\
\text { Gaming) }\end{array}$ & 1996 & $\begin{array}{l}\text { entrepreneurship } \\
\text { scholar }\end{array}$ & $\begin{array}{l}\text { Publication track } \\
\text { records }\end{array}$ & US & $\begin{array}{l}\text { Quantitative } \\
\text { study }\end{array}$ \\
\hline $\begin{array}{l}\text { Fiet } \\
\text { (Journal of } \\
\text { Business } \\
\text { Venturing) }\end{array}$ & $2001 a$ & $\begin{array}{l}\text { entrepreneurship } \\
\text { scholar }\end{array}$ & $\begin{array}{l}\text { Teaching } \\
\text { approaches }\end{array}$ & Global & $\begin{array}{l}\text { Content analysis } \\
\text { of EE-syllabi }\end{array}$ \\
\hline $\begin{array}{l}\text { Fiet } \\
\text { (Journal of } \\
\text { Business } \\
\text { Venturing) }\end{array}$ & $2001 b$ & $\begin{array}{l}\text { entrepreneurship } \\
\text { educator }\end{array}$ & $\begin{array}{l}\text { The teacher's role; } \\
\text { teaching strategies }\end{array}$ & Global & $\begin{array}{l}\text { Conceptual } \\
\text { paper }\end{array}$ \\
\hline $\begin{array}{l}\text { Doh } \\
\text { (Academy of } \\
\text { Management } \\
\text { Learning and } \\
\text { Education) } \\
\end{array}$ & 2003 & management educator & $\begin{array}{l}\text { Teaching } \\
\text { approaches }\end{array}$ & US & $\begin{array}{l}\text { Interviews with } \\
\text { leading scholars }\end{array}$ \\
\hline $\begin{array}{l}\text { Brush et al. } \\
\text { (Journal of } \\
\text { Management) }\end{array}$ & 2003 & $\begin{array}{l}\text { entrepreneurship } \\
\text { scholar }\end{array}$ & Career paths & US & $\begin{array}{l}\text { Method mix } \\
\text { (interviews and } \\
\text { survey) }\end{array}$ \\
\hline $\begin{array}{l}\text { Elmuti } \\
\text { (Management } \\
\text { Decision) }\end{array}$ & 2004 & management educator & $\begin{array}{l}\text { Educator types } \\
\text { (career academic } \\
\text { vs. Educator with } \\
\text { previous business } \\
\text { experience) }\end{array}$ & US & $\begin{array}{l}\text { Interviews with } \\
\text { leading scholars }\end{array}$ \\
\hline $\begin{array}{l}\text { Finkle } \\
\text { (Journal of } \\
\text { Entrepreneurship } \\
\text { Education) }\end{array}$ & 2007 & $\begin{array}{l}\text { entrepreneurship } \\
\text { scholar }\end{array}$ & $\begin{array}{l}\text { Faculty recruitment } \\
\text { (candidates and } \\
\text { open positions) }\end{array}$ & US & $\begin{array}{l}\text { Quantitative } \\
\text { study }\end{array}$ \\
\hline $\begin{array}{l}\text { Sarasvathy } \\
\text { (Book, Elgar } \\
\text { Publishing) }\end{array}$ & 2008 & $\begin{array}{l}\text { entrepreneurship } \\
\text { instructor }\end{array}$ & Teaching methods & US & $\begin{array}{l}\text { Conceptual } \\
\text { paper (based on } \\
\text { interviews with } \\
\text { founders) }\end{array}$ \\
\hline $\begin{array}{l}\text { Günther and } \\
\text { Wagner } \\
\text { (European Journal } \\
\text { of International } \\
\text { Management) }\end{array}$ & 2008 & $\begin{array}{l}\text { teachers and } \\
\text { instructors of } \\
\text { entrepreneurship }\end{array}$ & $\begin{array}{l}\text { Co-operation } \\
\text { between e- } \\
\text { educators and } \\
\text { technology transfer } \\
\text { activities }\end{array}$ & Europe & $\begin{array}{l}\text { Quantitative } \\
\text { study of } \\
\text { technology } \\
\text { transfer } \\
\text { institutions }\end{array}$ \\
\hline $\begin{array}{l}\text { Robbers } \\
\text { (IntEnt-conference } \\
\text { paper) }\end{array}$ & 2010 & $\begin{array}{l}\text { entrepreneurship } \\
\text { educator }\end{array}$ & $\begin{array}{l}\text { Status of the e- } \\
\text { educator's } \\
\text { professional field of } \\
\text { practice }\end{array}$ & Germany & Qualitative study \\
\hline $\begin{array}{l}\text { Kabongo and } \\
\text { McCaskey } \\
\text { (Journal of Small } \\
\text { Business and } \\
\text { Enterprise } \\
\text { Development) }\end{array}$ & 2011 & $\begin{array}{l}\text { entrepreneurship } \\
\text { educator }\end{array}$ & $\begin{array}{l}\text { Academic } \\
\text { qualification, } \\
\text { primary teaching } \\
\text { areas, research } \\
\text { interests and } \\
\text { journal publications }\end{array}$ & US & $\begin{array}{l}\text { Quantitative } \\
\text { study }\end{array}$ \\
\hline
\end{tabular}

Table 1: Examples of literature on management and/or entrepreneurship educators

The heterogeneity of existing literature makes it necessary to investigate in depth the findings that they have in common. We focus on select aspects which may contribute to an educator's mindset and teaching approach and thus may affect $E E$, starting with aspects of the educator 
profile, and with the best researched profile of EE practitioners. As a result we derive a working definition of the term "e-educator" for the present study.

\subsection{To what extent are practitioners being used in EE?}

Several scholars mention the use of practitioners - as full- or part-time adjunct faculty - to be an important part of entrepreneurship education (Plaschka and Welsch, 1990; Brockhaus, 1992; Katz, 1995; Katz, 2003). In the US, practitioners were originally involved in EE to compensate for a lack of tenured entrepreneurship faculty (Katz, 1995) ${ }^{1}$. The involvement of practitioners has since become widely accepted, "reflected in the high percentages of adjunct (i.e., nontenure track, part-time) faculty" (Katz, 2003, p. 297). This observation is questioned in a recent study by Kabongo and McCaskey (2011) who show a share of only 17 percent of adjunct/ part-time staff (p. 35) and suggest that their share might have been decreasing. Notwithstanding this possible decline, EE also involves practitioners as guest speakers (Solomon, 2007). While the EE-element of guest speakers is valued for "bringing the real world to class" (Gartner and Vesper, 1994, p. 187), their "erratic" speaking quality has led some US EE-programmes to give up this input (Gartner and Vesper, 1994, p. 183).

In addition to the real-world input there are two main reasons for the use of practitioners: the increase in EE-offerings and the resulting need for educators (Brush et al., 2003), and the finding that the introduction of entrepreneurial role models to the curriculum is an effective element to raise EE-participants' intention to start-up (Müller, 2009).

\footnotetext{
${ }^{1}$ In the Anglo-American higher education system the term "tenure" commonly refers to an academic position for life.
} 


\subsection{What academic qualification is required for teaching $\mathrm{EE}$ at universities?}

Entrepreneurship faculty can have an academic or a business background, or both. But what entrance qualification for teaching in academia exists, and to what extent do full-time and part-time faculty differ?

Both in the US and in Europe a Ph.D. is the prevalent degree among e-educators, with the majority of Ph.D.s in business / economic sciences. The US-based sample of e-educators assessed by Kabongo and McCaskey (2011) features 60 percent of e-educators holding a Ph.D. degree or equivalent (p. 34). The majority of these are full-time staff, whilst only 2 percent were adjunct / part-time staff (p. 35). In Germany, "entrepreneurship professors generally hold a Ph.D." (Schleinkofer and Kulicke, 2009, p. 30). We have not found published data on academic qualifications which other German e-educators currently hold.

\subsection{An interdisciplinary arena - reflected by diverse educational backgrounds?}

German entrepreneurship professors have much more diverse educational backgrounds than their US colleagues. Whether this is also the case for non-professorial staff in Europe and in the US remains open.

Reflecting the high expectations for e-educators "to know everything about every field" (Neck and Greene, 2011, p. 56), the profession of educators in this interdisciplinary field holds a wide spectrum of backgrounds and experience. These profiles encompass "academics, entrepreneurs, consultants, investors, full-time, part-time, academically qualified, and professionally qualified" (Neck and Greene, 2011, p. 56). Further, there is ongoing debate within EE on two opposed teaching approaches: the "specialist" and the "generalist" approach (cf. Béchard and Grégoire, 2005, p. 24). Both approaches lead to respective e-educators' 
profiles: the individual educator as "specialist" (e.g., teaching start-up finance) or "generalist" (e.g., teaching business planning, encompassing financial aspects).

As to educational backgrounds (incl. study degrees), existing research shows that entrepreneurship faculty in the US reflect the interdisciplinary nature of the field, holding degrees in disciplines as varied as management, psychology, anthropology or engineering (Katz, 2003; Brush et al., 2003). With the increase in EE-offerings, the diversity of educational backgrounds grows even further: according to Kabongo and McCaskey (2011), "educators from diversified disciplines such as industrial technology, psychology, art, music, engineering and the sciences have been invited to develop and teach entrepreneurship courses." (p. 29) Among German entrepreneurship professors at HEls, the spectrum of educational backgrounds has broadened into more diverse social sciences, e.g., psychology and sociology (cf. Klandt, 2004), but with a considerable majority of Ph.D. holders in business or economic sciences (Schleinkofer and Kulicke, 2009; 86.1\%). Schleinkofer and Kulicke (2009) also found that 11 percent of German entrepreneurship professors hold double degrees in business / economic sciences and engineering / technical studies (p. 45).

\subsection{Incorporating theory and practice - does the ideal profile exist?}

Published research in EE has repeatedly brought up the requirement for and difficulties in deploying educators who can bring their own entrepreneurial experience to the classroom (cf. Hills, 1988; Rabbior, 1990). McMullan and Long (1987) refer to the ideal of bringing both academic and entrepreneurial experience to the classroom as "not (...) as unlikely in the entrepreneurship field as [in] many others" (p. 268). The e-scholar and e-educator Fiet (2001b) proves that this ideal does indeed exist, recounting his own (multiple) start-up experiences ( $p$. 104). Nonetheless, due to the prerequisite of faculty's academic training, this requirement, however justified, proves to be difficult to fulfil in reality. 
In their study on entrepreneurship tenure requirements at US higher education schools and universities, Finkle et al. (2007) assess the share of tenured faculty members with start-up experience and find that 50 percent of all faculty members who have earned tenure have experience in starting at least one business (p. 109). More recently, Kabongo and McCaskey (2011) report that even 80 percent of US-e-educators claim entrepreneurial experience outside of the classroom (p. 38). The authors note that these activities encompass a "wide variety" of entrepreneurial experience, such as experience as consultant to start-ups (41\%), as business owner (36\%), as corporate executive and director of institutions (29\%), as entrepreneur (19\%), and in Venture Capital (5\%) (Kabongo and McCaskey, 2011, p. 38).

Klandt et al. (2008, p. 39) report an equally high share of 76 percent of entrepreneurship professors with entrepreneurial activities for Germany. The authors give details of these activities, which feature business start-ups alone or in a team as leading activity (61\%), followed by holding a stake in a company (36\%), corporate take-over (11\%), and running a family-owned business (8\%).

A direct comparison of these findings is not possible, due to inconsistent and overlapping terminology on entrepreneurial activities in the two surveys on the US and Germany.

\subsection{Working definition "entrepreneurship educator"}

In summary, actors in the field of EE form a "rich and diverse pool of collaborative educators [...] with a common understanding that entrepreneurship education is important" (Neck and Greene, 2011, p. 56). The present study builds on Neck and Greene's (2011) understanding. For the purpose of our study we refer to the term "e-educator" as follows: 
An e-educator can be any person ${ }^{2}$ in charge of running and / or managing an entrepreneurship course, independent of status and position at the university. An e-educator can thus be a professor, a teaching assistant, or an external lecturer. The e-educator is not necessarily involved in the design of the EE-course or of the whole programme. His / her roles not only include that of the teacher and trainer, but also increasingly that of the facilitator, e.g. when involving guest speakers (cf. Solomon, 2007). In this study the category of guest speakers is not considered as e-educators, but rather as a content component of EE.

\section{Methodology}

This study builds on a survey carried out at German private and public universities in 2010 .

\subsection{Sample}

In order to obtain our sample of entrepreneurship educator profiles, we identified over 500 EE-offerings at 76 universities. We applied simple random sampling with a stratified element (individual courses only, no complete EE-programmes), combined with a systematic element (curricular courses only, with Credit Points allocated). Special Master programmes in Entrepreneurship or pure academic offerings were not included in the sampling. The result is a sample of 76 curricular EE-offerings, with one EE-course each per university. We then contacted the 76 entrepreneurship scholars in charge of running the respective course and received 45 valid survey questionnaires, which corresponds to a response rate of $58 \%$.

\subsection{Categorisation of responding universities' "entrepreneurial" performance}

As part of the evaluation of our sample, we categorized the responding universities according to their "entrepreneurial" performance. We followed the existing ranking by Schmude and

\footnotetext{
2 Sarasvathy (2008) also refers to the respective educating institution as an "e-educator" (p. 310). For the purpose of this study such "institutional e-educators" are not encompassed by the term.
} 
Heumann (2011) and its underlying criteria. The "Schmude-ranking" is conducted regularly and published every two to three years. It measures the performance of German universities in the following eight areas: (1) EE, (2) extra-curricular qualification and support, (3) external network, (4) framework set by higher education policies, (5) cooperation and coordination, (6) communication, (7) mobilisation of target groups, (8) start-up activity. Schmude and Heumann (2011) have defined three performance categories which are highlighted in different colours (pp. 10-11). (1) "green area (= founder area)": universities with comparably good to very good offerings and services were awarded 200+ points in the survey; (2) "yellow area": universities with offerings and services of overall "comparably average" were awarded 100-199 points in the survey; and (3) "red area": universities offering "comparably bad" to "very bad" conditions for potential entrepreneurs obtained up to 99 points.

Based on this ranking our sample is composed of a "green" majority of universities of "high entrepreneurial performance" (53\%), a "yellow" share of universities of "medium entrepreneurial performance" (25\%) and of $22 \%$ private universities which have the reputation to be universities of high entrepreneurial performance, but are not included in the "Schmude-ranking". We will therefore assess this group separately.

This categorisation of German entrepreneurial universities based on established criteria allows us to compare educator profiles for the different types of universities in our sample. 


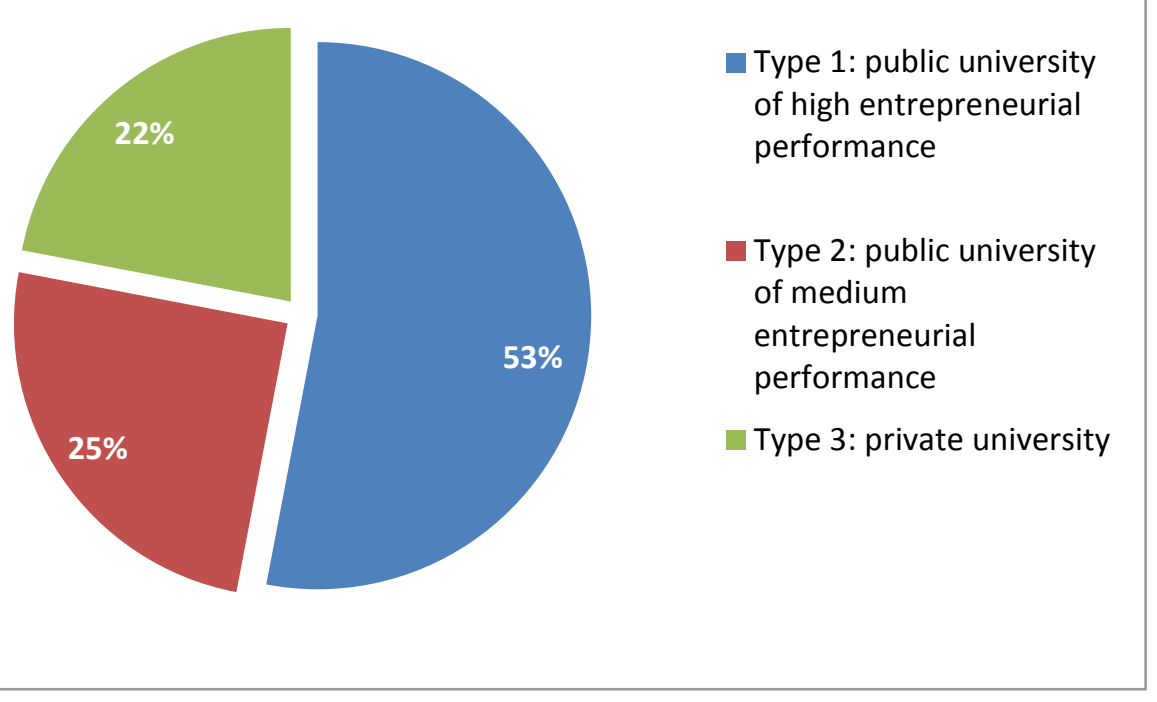

Figure 1: Distribution of universities by entrepreneurial performance in the sample

\subsection{Data analysis}

In order to compare our findings to the largely US-based published findings, we first evaluated the respondents' mean percentages in the following three content categories: academic qualification, educational background, and potential own entrepreneurial experience brought to the classroom. We compared the differences in the mean percentages across the three responding types of educators, the full-time tenured professors, teaching assistants, and adjunct / part-time instructors. This initial analysis of the entire sample allows us to fill the existing knowledge gap on e-educator profiles across German universities.

To determine whether the reported differences are significant, we conducted a nonparametric statistical test after having tested the sample for normal distribution which led to the rejection of the normal distribution hypothesis (cf. Janssen and Laatz, 2008, p. 254). In order to test for normal distribution we assessed skewness and curtosis. While the tests for skewness were within acceptable boundaries, the results for kurtosis were both below minus 1 , indicating a distribution with an abnormal peak (compressed). In addition, we ran a ShapiroWilk test, recommended for samples with under 50 observations (cf. Janssen and Laatz, 2005, 
p. 242). All tests showed that the distribution observed in the sample most likely does not stem from a normally distributed population.

The non-parametric statistic (2-tailed) for each category was evaluated to determine if the difference was significant at the levels of $p<.10$, respectively $p<.05$.

In a next step we introduced the three abovementioned categories of universities. Finally we compared the mean percentages in each of the five content categories across e-educators for each of the three groups of universities identified in the sample (inter-group comparison). We tested these results for significance through a non-parametric statistical test to determine if the differences between groups were significant at the levels of $p<.10$, respectively $p<.05$. We want to point out that we intend this university grouping only to provide additional information on e-educators' profiles. We cannot draw conclusions from the individual educator level to the level of the corresponding university, as our sample encompasses only one respondent per university.

In order to assess the possible impact of an e-educator's profile on teaching contents of $E E$, we evaluated the frequency with which the respondents apply a range of teaching contents. Finally, we assessed the significance of our findings based on the respective non-parametric statistical value for each of the teaching contents.

\section{Findings}

\subsection{Educator profiles in Germany}

The analysis of the 45 educators in our sample confirms that there is no consistent educator profile at German universities. Based on an evaluation of the three content categories of academic qualification, educational background and potential own entrepreneurial experience, the profiles in our sample are characterized as follows:

Academic qualification of external e-educators is high 
External / adjunct educators display a polarization of academic qualifications: while only 30 percent of them do not have a $\mathrm{PhD}, 43$ percent of them show a qualification equivalent to the prerequisite to apply for a chair ("Habilitation", cf. footnote 2).

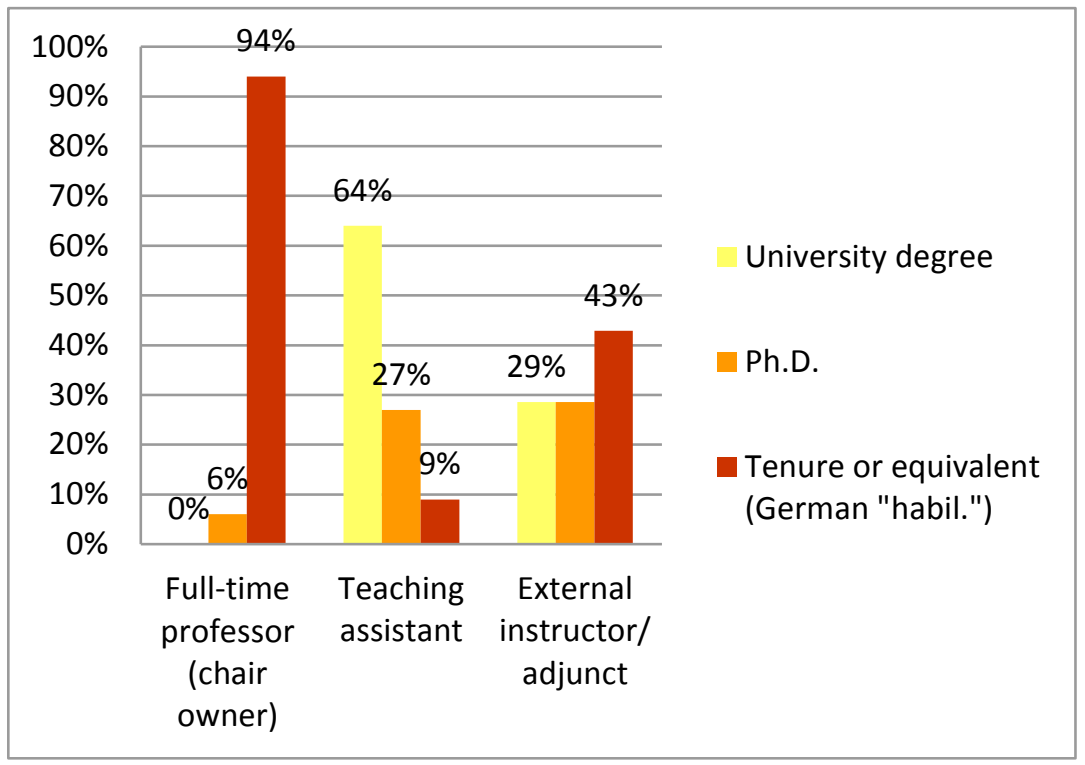

Figure 2: E-educators in the sample and their academic qualifications

The literature on e-educators reviewed for comparison includes little information on the academic qualifications of external instructors in the US. Kabongo and McCaskey (2011) mention that "[out] of 195 entrepreneurship faculty who held a PhD in [our] sample, about 3.08 percent were adjuncts" (p. 35). We therefore assume that in Germany, adjunct eeducators require considerably higher academic qualifications than their US-counterparts. This assumption has to be tested in a separate, more detailed, study, but is supported by the fact that German regulations require honorary professors to hold a Ph.D.

\section{E-educators predominantly have educational backgrounds in business/ economic sciences}

The vast majority of German academic e-educators have an educational background in business and economic sciences (89\%), including both pure management degrees (67\%) and degrees of non-business studies combined with management/ business studies (22\%). The most frequent combination was business and technical studies (11\%), followed by business 
and social sciences (9\%). Emphasizing the interdisciplinary character of $\mathrm{EE}$, some educators have multiple educational backgrounds, such as creative / business / social sciences (4\%), business / natural sciences (2\%) as well as social sciences / handicraft (2\%).

\section{2 percent of e-educators bring their own entrepreneurial experience to the classroom}

A remarkable share of all three groups of e-educators, both full- and part-time, demonstrates own entrepreneurial experience (62\%). 88 percent of responding professors (chair holders), 71 percent of responding external instructors and even 41 percent of teaching assistants can draw on own entrepreneurial experience.

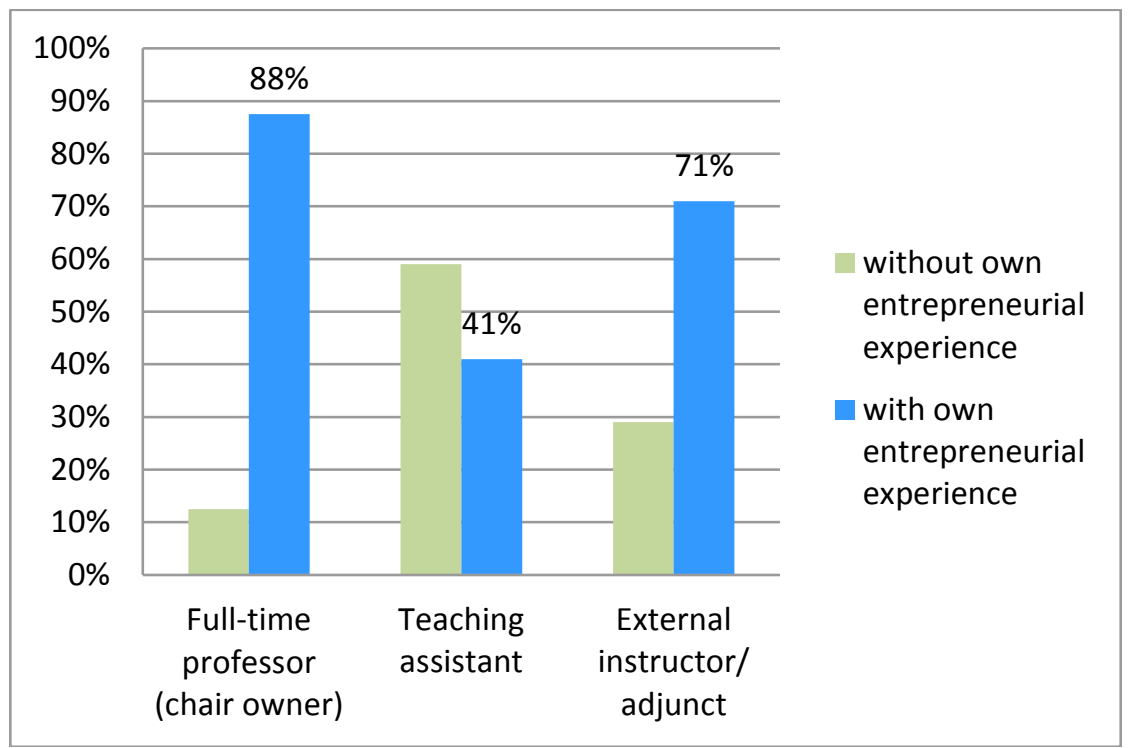

Figure 3: E-educators in the sample and their own entrepreneurial experience

Overall, every other e-educator with entrepreneurial experience in our sample held a professorship (chair). This is in line with a study on full-time professors by Finkle et al. (2007, p. 109) who found that half (50 percent) of all tenured faculty members had started at least one business.

\subsection{Inter-group comparison of educator profiles in Germany}

Our inter-group comparison of e-educator profiles at German universities of different entrepreneurial performance shows a distinct mix of faculty for each category: 
- Universities of high entrepreneurial performance host the biggest mix of educational backgrounds, often in combination with a business / economic sciences degree (88\%).

- Universities of medium entrepreneurial performance exclusively feature EE-staff with a business / economics background (100\%). A third of them show a combination with another background in technical studies.

- Privately funded universities show the highest share of educators with own entrepreneurial experience (90\%), followed by universities of high performance (60\%) and then medium performance (50\%). Like universities of medium performance, all educators at private universities have a background in business / economic sciences. However, they combine this with a wide range of other backgrounds, including social sciences (30\%) and the arts $(10 \%)^{3}$

There was a statistically significant difference between the university groups (Chi-square = $5.315, P=0.070)$, with a mean rank of 18.00 for universities of medium performance, 22.50 for universities of high performance and 29.25 for private universities. This underlines that privately funded universities in Germany have a statistically higher share of e-educators with own entrepreneurial experience, which is in line with their reputation.

\subsection{Potential impact of e-educators on EE}

To assess the potential impact of e-educators on the contents of $E E$, we focused on an analysis of the role of an educator's own entrepreneurial experience. To this end we asked the respondents to what extent their respective EE-course contained one or more of 16 different teaching elements. The list encompassed teaching methodologies and contents. Based on the average values of respondents' answers for every teaching element, we added to our analysis

\footnotetext{
${ }^{3}$ A test for significance of the share of educators with business / economic background in our sample showed no statistically significant differences between the different types of German universities.
} 
whether the responding educators had entrepreneurial experience or not. These two groups differ considerably in four content elements (cf. bold values in table below). A Pearson's Chisquare test confirmed the use of three EE-content elements by educators with entrepreneurial experience to be of statistical significance.

E-educators with start-up experience have an impact on teaching contents of $E E$, by preferring (1) the element of participants establishing their own network $\left(X^{2}=12.56, p=.002\right.$, hence $p$ $<.01)$; (2) the element of encouraging participants to critically reflect/ question $\left(X^{2}=8.20, p\right.$ $=.017$, hence $p<.05)$, and $(3)$ interdisciplinary elements $\left(X^{2}=6.88, p=.032\right.$, hence $\left.p<.05\right)$. 


\begin{tabular}{|c|c|c|c|c|}
\hline Activity & $\begin{array}{c}\text { E-educator with } \\
\text { own entrep. } \\
\text { experience }\end{array}$ & $\mathbf{N}$ & Average & SD \\
\hline \multirow{2}{*}{$\begin{array}{l}\text { Discussion elements } \\
\text { among participants ( } 1 \text { ) }\end{array}$} & No & 17 & 2.71 & .588 \\
\hline & Yes & 28 & 2.86 & .448 \\
\hline \multirow{2}{*}{$\begin{array}{l}\text { Business planning } \\
\text { elements ( } 2 \text { ) }\end{array}$} & No & 17 & 2.47 & .874 \\
\hline & Yes & 28 & 2.64 & .731 \\
\hline \multirow{2}{*}{$\begin{array}{l}\text { Action-oriented elements } \\
\text { (3) }\end{array}$} & No & 17 & 2.53 & .717 \\
\hline & Yes & 28 & 2.75 & .585 \\
\hline \multirow{2}{*}{$\begin{array}{l}\text { Interaction with practice } \\
(4)\end{array}$} & No & 17 & 2.41 & .870 \\
\hline & Yes & 28 & 2.61 & .685 \\
\hline \multirow[t]{2}{*}{ Mentoring elements (5) } & No & 17 & 1.71 & .849 \\
\hline & Yes & 28 & 2.11 & .875 \\
\hline \multirow{2}{*}{$\begin{array}{l}\text { Establishing own network } \\
\text { (6) }\end{array}$} & No & 17 & $\underline{1.53}$ & .874 \\
\hline & Yes & 28 & $\underline{2.43}$ & .790 \\
\hline \multirow{2}{*}{$\begin{array}{l}\text { Critical reflection/ } \\
\text { questioning ( } 7)\end{array}$} & No & 17 & $\underline{2.24}$ & .903 \\
\hline & Yes & 28 & $\underline{2.86}$ & .448 \\
\hline \multirow[t]{2}{*}{ Building a team (8) } & No & 17 & 2.24 & .903 \\
\hline & Yes & 28 & 2.50 & .839 \\
\hline \multirow{2}{*}{$\begin{array}{l}\text { Role models resp. founder } \\
\text { idols (9) }\end{array}$} & No & 17 & 2.00 & .791 \\
\hline & Yes & 28 & 2.25 & .844 \\
\hline \multirow[t]{2}{*}{ Lecture elements (10) } & No & 17 & 2.71 & .588 \\
\hline & Yes & 28 & 2.50 & .694 \\
\hline \multirow{2}{*}{$\begin{array}{l}\text { Interdisciplinary elements } \\
\text { (11) }\end{array}$} & No & 17 & $\underline{2.06}$ & 1.029 \\
\hline & Yes & 28 & $\underline{2.43}$ & .790 \\
\hline \multirow{2}{*}{$\begin{array}{l}\text { Simulation (e.g., training } \\
\text { game) (12) }\end{array}$} & No & 17 & 1.76 & .970 \\
\hline & Yes & 28 & 1.68 & .905 \\
\hline \multirow{2}{*}{$\begin{array}{l}\text { Own start-up during } \\
\text { seminar (13) }\end{array}$} & No & 17 & 1.59 & .870 \\
\hline & Yes & 28 & 1.93 & .900 \\
\hline \multirow[t]{2}{*}{ Internship in a start-up (14) } & No & 17 & 1.29 & .588 \\
\hline & Yes & 28 & 1.32 & .612 \\
\hline \multirow{2}{*}{$\begin{array}{l}\text { Training in negotiation } \\
\text { skills (15) }\end{array}$} & No & 17 & 1.35 & .606 \\
\hline & Yes & 28 & 1.39 & .685 \\
\hline \multirow[t]{2}{*}{ Video case study (16) } & No & 17 & 1.35 & .702 \\
\hline & Yes & 28 & 1.18 & .548 \\
\hline
\end{tabular}

Table 2: Comparison of mean values EE-content elements used between e-educators with and without own entrepreneurial experience in the sample (confirmed elements in bold and underlined)

Our findings show that the profile of e-educators at German universities can have both a direct and an indirect impact on EE:

- It can directly influence the actual teaching contents. In our sample, an educator's own entrepreneurial experience led to the significant preference for three teaching elements. 
- In addition, it can indirectly affect the actual effectiveness of EE. Müller (2009) has for example identified enabling participants to "build their own network" as an "effective" element to raise course participants' intentions to start-up. ${ }^{4}$

- Finally, publicly-financed universities of high entrepreneurial performance and privately funded universities seem to put particular emphasis on the employment of teaching staff with start-up experience who are likely to train these effective elements.

Overall, the study's findings show a significant diversity of educational backgrounds among eeducators at universities of high performance. This evidence suggests that such a profile mix contributes to the success of an institution's strive towards an entrepreneurial university.

\section{Conclusions and implications}

Our literature review has demonstrated that instead of a coherent picture of e-educators a plethora of rather "patchy" details currently exists. With regard to e-educators in Germany, we have only few references to compare our findings to, and the results are:

1. As in the US, there is no common e-educator profile yet in Germany.

2. In Germany, the level of academic qualification is considerably higher for external eeducators than in the US.

3. More than in the US, a background in business/ economic sciences is still the "educational background number one" among e-educators in Germany, either as only degree $(70 \%)$, or combined with a second degree (20\%). The potential effects of such a "monocultural" element on an interdisciplinary field are controversial.

4. The German entrepreneurship professors in our sample have as much experience in realworld entrepreneurship as their US-counterparts.

\footnotetext{
${ }^{4}$ Müller (2009) identifies "options for building up networks" by course participants as one of "seven educational variables (...) which can positively influence the antecedents of entrepreneurial intention" (p. 1).
} 
In addition, our findings allow for several new insights into different e-educator profiles, especially into those other than of full-time professors. In particular, a high percentage of eeducators in our sample have start-up experience, especially the external instructors (70\%), but also the teaching assistants (40\%).

The inter-group comparison of e-educator profiles across different university categories shows a distinct mix of faculty for each category. Most notably, universities of medium entrepreneurial performance feature a considerably higher share of EE-staff with a business / economics background. Compared to the best performing universities, they run the risk of a business "mono-culture" among their e-educators. Both privately funded universities and universities of high performance show high shares of educators with entrepreneurial experience. Universities of medium performance, on the other hand, might be able to influence their entrepreneurship rating by recruiting more interdisciplinary EE-staff.

Most importantly, our study has confirmed that the profile of an e-educator does have an impact on EE. This impact is not only a direct one, by way of influencing the actual teaching contents; it can also be an indirect one, by contributing to EE-effectiveness.

Overall, the above findings have implications at different levels: for EE in general, as well as for faculty and EE-offerings in the context of the entrepreneurial university in particular. According to a series of studies, the following implications equally apply to EE in Germany and in Europe (OECD, 2010; EU, 2003, 2006 and 2008).

General implications for Entrepreneurship Education

1. In the interdisciplinary field of entrepreneurship, educator profiles are heterogeneous, and this has positive effects on entrepreneurship teaching quality. Given the heterogeneity of e-educators in the US and in Germany, an introduction of standardised profiles would not only be difficult, but also counterproductive. As Neck and Greene (2011) 
point out, EE "requires teaching a method. (...) The method is peopledependent [sic] but not dependent on a type of person" (p. 57).

2. Entrepreneurship Education offerings could be improved by a common additional qualification of e-educators, rather than by an overall profile "standardisation". Such a common qualification would have to address current and future teaching staff. It should encompass the academic foundations of entrepreneurship as well as the practical foundations of teaching. Both new coherent doctoral programs in entrepreneurship (Brush et al., 2003) and a common basic (teaching) qualification for e-educators could deliver this. Well-known programmes in this area are Babson College's Modules for Entrepreneurship Educators (MEE) in the US as well as the qualification suggested by the international Network for Teaching Entrepreneurship (NFTE). However, there are also successful initiatives in Europe, as illustrated by the national Observatory of Pedagogical Practices in Entrepreneurship in France and the International Master of Entrepreneurship Education and Training in Denmark (OECD, 2010).

In the longer term, the development of an occupational profile for e-educators might allow for quality assurance.

3. Faculty profile is a key success factor. High performing universities show faculty with more diverse educational profiles and entrepreneurial experience. It is thus critical for universities to attract and keep the "right" type of educator. As this process might currently be hindered by a lack of mobility of educators across the EU, the coming years will see EU-initiatives to promote and support such mobility (EU, 2006).

4. It is not just the What and the How that matter, but also the Who. In particular, eeducators' own entrepreneurial experience not only enhances the reputation of a university's entrepreneurship programme (Kabongo and McCaskey, 2011), but also 
contributes indirectly and significantly to the effectiveness of EE in terms of raised startup intentions by students.

Implications for faculties and EE-offerings in the context of the entrepreneurial university

On a university level, the implications of our findings for the composition and recruitment of EE-faculty lead to four recommendations:

1. Embrace and leverage diversity: Our findings point out the potential of educator profiles to improve the quality of EE. This study thus supports Jones (2010) in his call for "appreciating the nature of heterogeneity in our classrooms" (p. 71). In a European context, this can be further enabled by HEls introducing "cross-discipline structures" (NIRAS Consultants et al., 2008).

2. Assess the current composition of EE-faculty: In order to leverage their potential to attract "the right kinds of educators - both academics and practitioners" (McMullen and Long, 1987, p. 272), universities first have to understand the "make-up" of their faculties. An initial assessment of EE-faculty with own entrepreneurial experience is only one example and a first step. We recommend a more comprehensive way of how universities can evaluate their teacher profiles, based on the concept of "the entrepreneurial leader" by Gibb et al. (2009): Building on literature including Clark's design of the entrepreneurial university organization (1998a and 2004) the authors present ten criteria (Gibb et al., 2009, fig. 6, p. 23) against which the profile of EE-faculty could be assessed.

3. Define the aspired EE-faculty composition: We recommend recruiting individual eeducators according to a university's desired EE-team composition. This might include balancing "specialist" and "generalist" staff as well as academically and practically experienced staff. At HEls across the EU, e-educators with own entrepreneurial experience do "not seem very widespread" (NIRAS Consultants et al., 2008, p. 6). This is not restricted 
to the EU, as reflected by a set of recommendations issued by the World Economic Forum (WEF) to all academic institutions: they encompass the guidance to "look to recruit professors and teachers who have entrepreneurship experience" (WEF, 2009, p. 26).

4. Never underestimate the power and effectiveness of role models: One of the effects of e-educators on EE is based on an educator's existing own start-up experience, as “(...) educators serve as role models. There are many academics who would not make good role models for future entrepreneurs" (McMullen and Long, 1987, p. 268). The present study shows how role models affect EE.

\section{Recommendations for future research}

We have evaluated a snapshot of e-educator profiles on a national level and their implications for content and effectiveness of EE. The shortcomings of this design lead to three directions for complementary research: It would be of interest to assess the effects of educator profiles on German EE with a longitudinal design, and to expand the current single-informant design with one e-educator per university to a multi-informant one. Including different organisational levels within a university (staff level - chair level - department level - head of university) would shed light on a university's EE-strategy and resource allocation. Finally, comparative studies between regions or countries are a further research area. In this context, it would also be of interest to apply a different and more cross-national approach to the evaluation of a university's entrepreneurial profile. Whilst we decided to follow an existing ranking which is established in Germany, there is a range of other potential criteria for evaluation. However, examples like the traditional criteria for assessment of any kind of education organisation by the Malcolm Baldrige National Quality Award in the US (cf. Vesper and Gartner, 1997) as well as those by NIRAS Consultants et al. (2008), applied for a European benchmark of university performance in $\mathrm{EE}$, do not account for the requirements of an entrepreneurial organisation. 
For further research beyond Germany we therefore suggest using ten aspects of specific organisational design - published by the British National Council for Graduate Entrepreneurship (NCGE) - as evaluation criteria (cf. Gibb et al., 2009, p. 17), and apply a Likertscale.

Several other knowledge gaps have arisen throughout our research. A first promising area for future research would be the entrepreneurial university's staff: what exactly are faculty's entrepreneurial competencies, how can they be defined, and what do they contribute to the overall performance of the university? In addition, it is of interest to obtain detailed information on the current composition of EE-faculties (teams). This would allow for a better understanding of current EE-teams as well as for the comparison between universities of different entrepreneurial performance.

\section{Acknowledgement}

The author of this study gratefully acknowledges the support of the German Association for Entrepreneurship-Research, -Education and -Policy (Förderkreis Gründungs-Forschung e.V. Entrepreneurship Research (FGF e.V.)) in the process of data collection. 


\section{References}

Béchard, J. and D. Grégoire (2005), 'Entrepreneurship education revisited: The case of Higher Education', Academy of Management Learning and Education, 4(1), 22-43.

Brockhaus, R.H. (1992), 'Entrepreneurship education: A research agenda', in H. Klandt and D. Müller-Böling (eds), Internationalizing Entrepreneurship Education and Training: Proceedings of the IntEnt 92 Conference, Dortmund, 23-26 June 1992, Dortmund: Förderkreis Gründungs-Forschung: FGF-Entrepreneurship-Research-Monographien,37.

Brush, C., I. Duhaime, W. Gartner, A. Stewart, J.A. Katz, M. Hitt, S. Alvarez, G.D. Meyer and S. Venkataraman (2003), 'Doctoral education in the field of entrepreneurship', Journal of Management, 29(3), 309-31.

Clark, B.R. (1998), Creating Entrepreneurial Universities: Organizational Pathways of Transition, Oxford: IAU Press/Elsevier.

Clark, B.R. (2004), 'Delineating the character of the entrepreneurial university', Higher Education Policy, 17(4), 355-70.

Doh, J.P. (2003), 'Can leadership be taught? Perspectives from management educators', Academy of Management Learning and Education, 2(1), 54-67.

Elmuti, D. (2004), 'Can management be taught?’ Management Decision, 42(3/4), 439-53. EU Commission of the European Communities (2003), Green Paper: Entrepreneurship in Europe, Brussels: EU, COM (2003) 27 final.

EU (2006), Entrepreneurship Education in Europe: Fostering Entrepreneurial Mindsets through Education and Learning, final proceedings of the Conference, Oslo, 26-27 October, European Commission. 
Fayolle, A., B. Gailly and N. Lassas-Clerc (2006), 'Assessing the impact of entrepreneurship education programmes: A new methodology', Journal of European Industrial Training, 30(8/9), 701-20.

Fiet, J.O. (2001a), 'The theoretical side of teaching entrepreneurship', Journal of Business Venturing, 16(1), 1-24.

Fiet, J.O. (2001b), 'The pedagogical side of entrepreneurship theory', Journal of Business Venturing, 16(2), 101-17.

Finkle, T.A. (2007), 'Trends in the market for entrepreneurship faculty from 1989-2005', Journal of Entrepreneurship Education, 10, 1-24.

Finkle, T.A., P. Stetz and M. Mallin (2007), 'Perceptions of tenure requirements and research records of entrepreneurship faculty earning tenure: 1964-2002', Journal of Entrepreneurship Education, 10, 101-25.

Gartner, W.B. and K.H. Vesper (1994), 'Executive forum: Experiments in entrepreneurship education: successes and failures', Journal of Business Venturing, 9(3), 179-87.

Günther, J. and K. Wagner (2008), 'Getting out of the ivory tower - new perspectives on the entrepreneurial university', European Journal of International Management, 2(4), 400417.

Gibb, A., G. Haskins and I. Robertson (2009), Leading the Entrepreneurial University. Meeting the Entrepreneurial Development Needs of Higher Education Institutions, published by The National Council for Graduate Entrepreneurship (NCGE) and Saïd Business School, University of Oxford.

Haase, H. and A. Lautenschlaeger (2013), 'The ATMO-Matrix: A typology for entrepreneurship education at universities', in A. Fayolle et al. (ed.), Handbook of Research in 
Entrepreneurship Education, Vol. 4, Entrepreneurial University Handbook, Cheltenham, UK and Northampton, MA, USA: Edward Elgar (forthcoming).

Halbfas, B.G. (2006), 'Entrepreneurship education an Hochschulen - Eine wirtschaftspädagogische und -didaktische Analyse', dissertation, Bergische Universität Wuppertal, Paderborn: Eusl.

Henry, C., F. Hill and C. Leitch (2005), 'Entrepreneurship education and training: Can entrepreneurship be taught? Part I', Education 1 Training, 47(2), 98-111.

Hills, G.E. (1988), 'Variations in university entrepreneurship education: An empirical study of an evolving field', Journal of Business Venturing, 3(1), 109-22.

Hofer, A. et al. (2010), 'From strategy to practice in university entrepreneurship support: Strengthening entrepreneurship and local economic development in Eastern Germany: Youth, entrepreneurship and innovation', OECD Local Economic and Employment Development (LEED) Working Papers, 2010/09, OECD Publishing.

Janssen, J. and W. Laatz (2005), Statistische Datenanalyse mit SPSS für Windows 5, neu bearbeitete und erweiterte Auflage, Berlin/Heidelberg/New York: Springer-Verlag.

Jones, C. (2010), 'Accounting for student/educator diversity: Resurrecting coactions theory', in A. Fayolle (ed.), Handbook of Entrepreneurship Education, Vol. 3, International Perspectives, Cheltenham, UK and Northampton, MA, USA: Edward Elgar, pp. 71-85. Kabongo, J.D. and P.H. McCaskey (2011), 'An examination of entrepreneurship educator profiles in business programs in the United States', Journal of Small Business and Enterprise Development, 18(1), 27-42.

Katz, J.A. (1995), 'Managing practitioners in the entrepreneurship class', Simulation and Gaming, 26(3), 361-75. 
Katz, J.A. (2003), 'The chronology and intellectual trajectory of American entrepreneurship education 1876-1999', Journal of Business Venturing, 18(2), 283-300.

Katz, J.A. and R.P. Green (1996), 'Academic resources for entrepreneurship education', Simulation and Gaming, 27(3), 365-74.

Klandt, H. (2004), 'Entrepreneurship education and research in German-speaking Europe', Academy of Management Learning and Education, 3(3), 293-301.

Klandt, H., L.T. Koch, J. Schmude and U. Knaup (2008), FGF-Report 2008. EntrepreneurshipProfessuren an deutschen Hochschulen: Ausrichtung, Organisation und Vernetzung, Bonn/ Germany: FGF - Förderkreis Gründungs-Forschung e.V.

Matlay, H. (2010), 'Stakeholder participation in, and impact upon, entrepreneurship education in the UK', in A.A. Fayolle (ed.), Handbook of Entrepreneurship Education, Vol. 3, International Perspectives, Cheltenham, UK and Northampton, MA, USA: Edward Elgar, pp. 110-21.

McMullan, W.E. and W.A. Long (1987), 'Entrepreneurship education in the nineties', Journal of Business Venturing, 2(3), 261-75.

Müller, S. (2009), 'Encouraging future entrepreneurs: The effect of entrepreneurship course characteristics on entrepreneurial intention', dissertation, Universität St. Gallen, Switzerland.

Neck, H.M. and P.G. Greene (2011), 'Entrepreneurship education: Known worlds and new frontiers', Journal of Small Business Management, 49(1), 67-68.

NIRAS et al. (2008), Survey of Entrepreneurship in Higher Education in Europe, October 2008, requested by the European Commission, Directorate-General

for Enterprise and Industry, accessed 13 August at http://ec.europa.eu/enterprise/policies/sme/files/support_measures/ 
training_education/highedsurvey_en.pdf.

Peterman, N. and J. Kennedy (2003), 'Enterprise education: Influencing students' perceptions of entrepreneurship', Entrepreneurship Theory and Practice, 28(2), 129-35.

Pittaway, L. and J. Cope (2007), 'Entrepreneurship education: A systematic review of the evidence', International Small Business Journal, 25(5), 479-510.

Plaschka, G.R. and H.P. Welsch (1990), 'Emerging structures in entrepreneurship education: Curricular designs and strategies', Entrepreneurship Theory and Practice, 14(3), 55-71. Potter, J. (ed.) (2008), Entrepreneurship and Higher Education, Paris: OECD Publications.

Rabbior, G. (1990), 'Elements of a successful entrepreneurship/economics education program', in C.A. Kent, (ed.), Entrepreneurship Education. Current Developments, Future Directions, New York: Quorum Books, pp. 53-65.

Robbers, I. (2010), 'Pedagogical professionalism of the entrepreneurship educator', paper presented at the Conference Internationalizing Entrepreneurship Education and Training (IntEnt), 5-8 July 2010, at the HAN University of Applied Sciences, Arnhem [unpublished].

Sarasvathy, S.D. (2008), Effectuation. Elements of Entrepreneurial Expertise, Cheltenham, UK and Northampton, MA, USA: Edward Elgar Publishing.

Schleinkofer, M. and M. Kulicke (2009), Entrepreneurship Education an deutschen Hochschulen - Studie der wissenschaftlichen Begleitforschung zu 'EXIST Existenzgründungen aus der Wissenschaft', Stuttgart: Fraunhofer Verlag.

Schmude, J. and S. Heumann (2011), Vom Studenten zum Unternehmer: Welche Universität bietet die besten Chancen, published by the Lehrstuhl für Wirtschaftsgeographie und Tourismusforschung der Ludwig-Maximilians-Universität, Munich. 
Shepherd, D. (2004), 'Educating entrepreneurship students about emotion and learning from failure', Academy of Management Learning and Education, 3(3), 274-87.

Solomon, G. (2007), 'An examination of entrepreneurship education in the United States', Journal of Small Business and Enterprise Development, 14(2), 168-82.

Vesper, K.H. and W.B. Gartner (1997), 'Measuring progress in entrepreneurship education', Journal of Business Venturing, 12(5), 403-22.

World Economic Forum (2009), Educating the Next Wave of Entrepreneurs. Report on Entrepreneurship Education, Executive Summary, accessed 13 August 2013 at http://www3.weforum.org/docs/WEF_GEI_EducatingNextEntrepreneurs_ExecutiveS ummary_2009.pdf. 